JMLE

JOURNAL OF

MEDIA LITERACY

EDUCATION

\title{
BOOK REVIEW \\ Fact vs. fiction: Teaching critical thinking skills in the age of fake news
}

\section{○open ACCESS}

Book review

Citation: Carter, M. (2019). Book review: Fact vs. fiction: Teaching critical thinking skills in the age of fake news. Journal of Media Literacy Education, 11(3), 98-100. Doi: 10.23860/JMLE-2019-11-3-10

\section{Corresponding Author:}

Morgan Carter

morgancarter4@my.unt.edu

Copyright: () 2019 Author(s). This is an open access, peer-reviewed article edited by NAMLE, published by Bepress and distributed under the terms of the Creative Commons Attribution License, which permits unrestricted use, distribution, and reproduction in any medium, provided the original author and source are credited.

Received: April 9, 2019

Accepted: April 17, 2019

Published: November 30, 2019

Data Availability Statement: All relevant data are within the paper and its Supporting Information files.

Competing Interests: The Author(s) declare(s) no conflict of interest.

\section{Editorial Board}

\author{
Morgan Carter \\ University of North Texas
}

LaGarde, J., \& Hudgins, D. (2018). Fact vs. fiction: Teaching critical thinking skills in the age of fake news. USA: International Society for Technology in Education.

\section{Journal of Media Literacy Education}

THE OFFICIAL PUBLICATION OF THE

National Association for Media Literacy Education (NAMLE)

Online at www.jmle.org 
The notion of fake news has been discussed widely since the 2016 U.S. Presidential election (Allcott \& Gentzkow, 2017; Mason, Krutka, \& Stoddard, 2018; Pennycook, Cannon, \& Rand, 2018). While misinformation, disinformation, and propaganda have been going on for centuries (Shu, Sliva, Wang, Tang, \& Liu, 2017), the spread of fake news has exploded with the use of social media (Bulger \& Davison, 2018). With no apparent end in sight, there is not a timelier book on critical thinking and fake news than Fact vs. Fiction: Teaching Critical Thinking Skills in the Age of Fake News.

This book, published by the International Society for Technology in Education (ISTE), is one of the first publications from a major educational technology organization to address fake news head on. Jennifer LaGarde and Darren Hudgins do an excellent job of explaining fake news from how it developed this point to practical strategies that will help combat this growing phenomenon. The book is laid out succinctly over eight chapters and includes understanding checks at the end of each chapter, thoughts and reflection opportunities via Twitter, and numerous resources to help educators get started.

A race to be first sets the stage for the rest of the book. "First person accounts shared on social media as the news events happen are the new primary sources of our time" (LaGarde \& Hudgins, 2018, p. 2). Gone are the days of waiting for all the facts to emerge before reporting the news. This often leads to the misreporting of facts, which can then lead to all the other variations of fake news discussed later in this review. By enabling everyone, not just students, to discern facts from fiction and avoid being first and getting it wrong, the authors believe we can make progress toward a more skilled and informed society.

Chapter 1 unpacks the "why this book" and "why now" questions and the authors provide justification. First, the authors cite a 2017 Pew Research Center poll that shows, " $67 \%$ of Americans get at least some of their news from social media" (LaGarde \& Hudgins, 2018, p. 13) and this number continues to grow. Second, logic and reason are ignored in favor of deeply held personal beliefs along with an increasing distrust in today's media. However, media is not explicitly defined in the book. With a growing social media presence and a decline in media trust, the authors see "skilled teachers as the kryptonite against fake news and the purveyors of a better democracy" (LaGarde \& Hudgins, 2018, p. 15).

As mentioned earlier, propaganda and fake news have been going on for quite some time. Chapter 2 sheds light on how "deliberate attempts to manipulate public opinion in order to further a personal or political agenda" (LaGarde \& Hudgins, 2018, p. 19) trace back to America's Founding Fathers. The authors state that the tradition continues today and while technology might have exacerbated this problem, we are the ones to blame. Striking while the iron is hot using various media literacy tools and strategies will help us knock back fake news. Similar media literacy strategies are being proposed elsewhere that include teaching students to read laterally, teaching students to understand search results, and informing students that Wikipedia should not be the only source of information (McGrew, Ortega, Breakstone, \& Wineburg, 2017).

Fake news, propaganda, misinformation, disinformation, post-truth, and many other words/phrases are used to describe this phenomenon. Chapter 3 explores the many nuances of fake news and the ways in which information is consumed. From social media, blogs, wikis, television, print, and everything in between, information is now produced and consumed across a wide spectrum of platforms. News, both real and fake, is available for consumption $24 \times 7$ and the authors discuss "fake news fatigue" (LaGarde \& Hudgins, 2018, p. 42) that is made available via smartphones and push notifications. We live in a continuously plugged-in society and the barrage of information has diminished our ability to critically evaluate the information we consume. Quality media literacy instruction is needed now more than ever.

Chapter 4 takes a look at our brains on fake news and how we process information. As mentioned earlier, logic and reason are sometimes ignored for other emotional feelings and the purveyors of fake news are aware of this. "This attack on empathy is at the heart of what makes fake news so insidious and, as such, must also be at the heart of how we approach media literacy with our students" (LaGarde \& Hudgins, 2018, p. 53). Constant repetition also erodes our ability to make sound judgements. When information is presented over and over, whether true or not, it starts to feel real. The authors provide strategies like being aware of our own biases and giving students the chance to reflect core skills of media literacy, and offer advice for not feeding the fake news monster.

Due to the endless information available at our fingertips, it is becoming more difficult to judge what is fact and what is fiction, even for some trained experts. Chapter 5 offers of a wealth of assessments that can be used by anyone to better understand fake news and their own consumption of it. A quick assessment of myself 
revealed that real news is getting harder to spot, especially when viewed on a mobile device. This chapter offers a great starting place for any classroom to assess student's fake news detection skills, and "many of the resources you'll find there were recommended by educators" (LaGarde \& Hudgins, 2018, p. 77). The authors provide notes about each example that can be used as discussion starters in the classroom.

If additional resources are needed, Chapter 6 provides them. Over 50 resources are available that cover everything from frameworks and tips for determining credibility to sample lesson plans that are identified by grade level. QR codes are provided for easier access and switching quickly among resources. One of the key ideas presented by the authors is that we all have a part in combating this phenomenon. It is not just up to teachers and librarians to fight fake news; it is the responsibility of everyone who is a producer and consumer of information. Media literacy should be part of everyone's skill set.

Chapter 7 provides voices from the field. Teachers, librarians, and systems managers from across the U.K. and U.S. share their stories of how they are using teaching lessons in their environments to increase critical thinking skills and combat fake news. A question on page 121 asks, "Do you have any tips for educators," solicited the response: “...the biggest advice that I'd offer is, - Get started! Now - ." Those interviewed all indicated fake news is a problem but can be minimized with proper education and awareness.

The final chapter emphasizes the need for critical thinking now more than ever. Efforts to prevent the spread of false information are being made by big tech companies using artificial intelligence (Lazer et al., 2018); however, the onus is still on us to help spot and prevent the spread of bad information. The authors close with additional tips and encouragement for the challenging work ahead. "We are optimistic about the outcome, because we believe in the power of educators to change the world" (LaGarde \& Hudgins, 2018, p. 131).

Jennifer LaGarde and Darren Hudgins' work could not have come at a better time. The phenomenon of fake news seems to grow each day and really took off after the 2016 U.S. Presidential election - and the next election is rapidly approaching. One of the book's shortcomings is that it seems to be written specifically for K12 educators; however, this is reasonable given that it is published through an organization whose main focus is K12 education. Because the book can be utilized by most anyone wanting to teach critical thinking skills related to fake news, more examples and recommendations for populations outside of K12 would have been welcome.

\section{REFERENCES}

Allcot, H., \& Gentzkow, M. (2017). Social media and fake news in the 2016 election. Journal of Economic Perspectives, 31(2), 211-236.

Bulger, M., \& Davison, P. (2018). The promises, challenges, and futures of media literacy. Journal of Media Literacy Education, 10(1), 1-21.

LaGarde, J., \& Hudgins, D. (2018). Fact vs. fiction: Teaching critical thinking skills in the age of fake news. USA: International Society for Technology in Education.

Lazer, D. M., Baum, M. A., Benkler, Y., Berinsky, A. J., Greenhill, K. M., Menczer, F., ... \& Zittrain, J. L. (2018). The science of fake news. Science, 359(6380), 1094-1096.

Mason, L. E., Krutka, D., \& Stoddard, J. (2018). Media literacy, democracy, and the challenge of fake news. Journal of Media Literacy Education, 10(2), 1-10.

McGrew, S., Ortega, T., Breakstone, J., \& Wineburg, S. (2017). The challenge that's bigger than fake news: Civic reasoning in a social media environment. American Educator, 41(3), 4-9.

Pennycook, G., Cannon, T. D., \& Rand, D. G. (2018). Prior exposure increases perceived accuracy of fake news. Journal of experimental psychology, 147(12), 1865-1880.

Shu, K., Sliva, A., Wang, S., Tang, J., \& Liu, H. (2017). Fake news detection on social media: A data mining perspective. ACM SIGKDD Explorations Newsletter, 19(1), 22-36. 